\title{
Nilai Religius dan Eksistensi Perempuan dalam Novel Cinta Di Ujung Sajadah Karya Asma Nadia
}

\author{
Hendar \\ Universitas Indraprasta PGRI \\ Jalan Nangka No. 58 C/TB. Simatupang, Tanjung Barat, Jakarta Selatan 12530
}

\begin{abstract}
The purpose of this research is to describe the religious values and existence of women in Cinta di Ujung Sajadah by Asma Nadia. Data collection techniques in this study used an objective approach to data analysis using content analysis. In this case, the researcher will reveal the contents or religious values and the existence of women contained in the novel Cinta di Ujung Sajadah by Asma Nadia. The results of the study the value of faith (faith) is 10 citations with a percentage of $15.15 \%$, Sharia values (worship), are 3 quotes with a percentage of $4.55 \%$, moral values (character), including found 7 quotes with a percentage of $10.61 \%$, the existence of women as individuals there are 28 quotes with a percentage of $42.42 \%$. The existence of women as family members of Asma Nadia's work there are 13 quotes with a percentage of $19.70 \%$. The existence of women as members of the community there are 5 quotes with a percentage of $7.57 \%$.
\end{abstract}

Keywords: Religious value, the Existence of Women.

\begin{abstract}
Abstrak
Tujuan penelitian adalah untuk mendeskripsikan nilai-nilai religius dan eksistensi perempuan dalam Cinta di Ujung Sajadah karya Asma Nadia. Teknik pengumpulan data dalam penelitian ini menggunakan pendekatan objektif dengan analisis data menggunakan analisis isi (Content Analysis). Dalam hal ini, peneliti akan mengungkapkan isi atau nilai-nilai Religius dan eksistensi perempuan yang terkandung dalam novel Cinta di Ujung Sajadah karya Asma Nadia. Hasil penelitian Nilai akidah (keimanan) adalah 10 kutipan dengan persentase 15,15\%. Nilai Syariah (ibadah), adalah 3 kutipan dengan persentase 4,55\%, Nilai akhlak (budi pekerti), meliputi ditemukan 7 kutipan dengan persentase 10,61\%, Eksistensi perempuan sebagai pribadi terdapat 28 kutipan dengan persentase $42,42 \%$. Eksistensi perempuan sebagai anggota keluarga karya Asma Nadia terdapat 13 kutipan dengan persentase $19,70 \%$. Eksistensi perempuan sebagai anggota masyarakat terdapat 5 kutipan dengan persentase $7,57 \%$.
\end{abstract}

Kata Kunci: Nilai Religius, Eksistensi Perempuan.

\section{PENDAHULUAN}

Pada dasarnya kehidupan manusia sangatlah kompleks dengan berbagai masalah kehidupan. Kehidupan yang kompleks tersebut terdapat beberapa permasalahan yang mencakup hubungan manusia dengan Tuhannya (Hubungan Vertikal) dan hubungan manusia dengan manusia (Hubungan Horizontal). Keberadaan karya sastra jenis novel yang bertema keagamaan semakin merebak. Hal itu bisa dilihat dari bermunculannya para pengarang yang novelnya bernapaskan keagamaan, dalam hal ini bernapaskan Islam. Salah satu novel bernapaskan Islam yang mencerminkan nilai-nilai religius adalah novel Cinta di Ujung Sajadah karya Asma Nadia. Novel Cinta di Ujung Sajadah tersebut 
termasuk novel Islami. Dalam novel Cinta di Ujung Sajadah terdapat nilai-nilai religius karena adanya hubungan intertekstual dengan teks lain, dalam hal ini adalah teks Al-Quran dan Hadis sebagai hipogramnya. Untuk itu, perlu dilakukan penelitian yang memfokuskan perhatian pada kajian intertekstual. Berdasarkan alasan-alasan itu penulis menganggap penting dan menarik untuk meneliti novel Cinta di Ujung Sajadah dari perspektif intertekstual, dengan judul "Nilai-nilai Religius dalam Cinta di Ujung Sajadah (Kajian Intertekstual)”.

Novel ini menceritakan tentang kerinduan seorang anak kepada ibunya serta perjuangannya mencari tahu bagaimana sosok ibu kandungnya yang tidak pernah ia temui. Novel Cinta di Ujung Sajadah ini sangat mengesankan dilihat dari pribadi seorang perempuan yang memiliki sifat pantang menyerah dan mampu berjuang mencari kebenaran dalam hidupnya yang belasan tahun tidak ia ketahui. Gadis cantik dengan keberaniannya yang besar, tanpa ragu dan tanpa keputusan ini akhirnya menemukan kebenaran mengenai ibu kandungnya. Bentuk perjuangan dalam novel Cinta di Ujung Sajadah karya Asma Nadia membuktikan bahwa perempuan memiliki kemampuan untuk mengatasi masalah ataupun konflik yang ada dalam kehidupannya.

Penulis memilih novel Cinta di Ujung Sajadah karya Asma Nadia untuk diteliti. Asma Nadia merupakan salah satu pengarang perempuan Indonesia yang sangat produktif. Selain menulis, Asma Nadia juga sebagai pembicara dalam berbagai lokakarya yang berkaitan dengan penulisan dan feminisme, baik di dalam dan di luar negeri. Melalui novelnya yang berjudul Cinta di Ujung Sajadah, Asma Nadia menyampaikan beberapa nilai moral atau pesan moral. Nilai moral yang terkandung dalam novel Cinta di Ujung Sajadah sangat baik untuk pendidikan religius khususnya remaja. Nilai-nilai religius tersebut dapat memberikan dampak dan perubahan yang baik kepada pembaca.

Tokoh-tokoh yang ada dalam novel memiliki karakter yang berbeda-beda dan tentunya mereka memiliki moral yang baik pula. Mereka adalah Cinta, Makky, Salsa, Aisyah, dan Neta. Kelima orang itu adalah tokoh novel yang sangat berpengaruh terhadap jalan cerita. Salah satu nilai religius yang terkandung dalam novel ini adalah ketika mereka berada dalam keadaan yang sangat sulit, tetapi mereka saling tolong-menolong terhadap sesama.

Novel Cinta di Ujung Sajadah karya Asma Nadia memiliki alur cerita yang merupakan pencerminan dunia realitas yang dialami oleh seorang wanita di tengahtengah keluarga dan masyarakat sehingga ceritanya benar-benar hidup. Novel Cinta di Ujung Sajadah karya Asma Nadia merupakan sebuah novel inspiratif.

Novel Cinta di Ujung Sajadah karya Asma Nadia menarik dan layak dibaca pelajar, mahasiswa, dan masyarakat pada umumnya karena dapat memberikan motivasi dan semangat kepada pembaca untuk terus berjuang mencapai impian dan cita-cita. Selain itu, novel tersebut memberikan pengetahuan nilai-nilai moral yang baik untuk kehidupan di dalam keluarga dan bermasyarakat.

Untuk Memudahkan tujuan penelitian, penulis memaparkan beberapa teori yang dikemukakan oleh beberapa ahli untuk memudahkan tujuan penelitian beberapa teori tersebut adalah tentang hakikat nilai religius, dan eksistensi perempuan dalam novel.

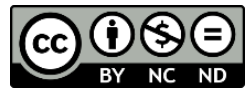


Awal mulanya, segala sastra adalah religius atau religiositas. Religiositas berbeda dengan agama. Agama lebih menunjuk kepada kelembagaan kebaktian kepada Tuhan dalam aspeknya yang resmi atau yuridis melalui peraturan dan hukum, keseluruhan organisasi tafsir alkitab dan sebagainya yang melingkupi segisegi kemasyarakatan, sedangkan religiositas lebih melihat aspek yang ada di dalam lubuk hati atau sikap personal yang sedikit banyak adalah misteri bagi orang lain. Sikap religius, seperti berdiri khidmat, membungkuk dan mencium tanah selaku ekspresi bakti menghadap Tuhan, mengatupkan mata selaku konsentrasi diri pasrah dan siap mendengarkan sabda Ilahi dalam hati (Mangunwijaya, 1988: 11-12).

Nilai atau value (bahasa Inggris) atau valaere (bahasa Latin) yang berarti: berguna, mampu akan, berdaya, berlaku dan kuat. Nilai merupakan kualitas suatu hal yang dapat menjadikan hal itu disukai, diinginkan, berguna, dihargai dan dapat menjadi objek kepentingan.

Dalam ajaran Islam hubungan itu tidak hanya sekadar hubungan dengan Tuhan-nya akan tetapi juga meliputi hubungan dengan manusia lainnya, masyarakat atau alam lingkungannya (Asmuni, 1997:2)

Nilai religius adalah nilai-nilai kehidupan yang terdiri dari tiga unsur pokok, yaitu akidah, ibadah, dan akhlak yang menjadi pedoman perilaku sesuai dengan aturan-aturan Ilahi untuk mencapai kesejahteraan serta kebahagiaan hidup di dunia dan akhirat (Sahlan, 2012: 42). Hal tersebut sependapat dengan Ali. Ali (2013: 365) mengungkapkan bahwa komponen-komponen dasar agama Islam yaitu iman (akidah), takwa (syariat/ ibadah), dan budi pekerti luhur (akhlakul karimah). Religius adalah suatu keadaan yang ada dalam diri manusia yang mendorong bertingkah laku baik, sesuai ajaran agama yang dianutnya dalam kehidupan seharihari demi memperoleh rida atau perkenan Tuhannya.

Berdasarkan beberapa pendapat di atas, dapat disimpulkan bahwa di setiap karya sastra terdapat nilai religius. Nilai religius mencakup iman, takwa, dan akhlak. Orang yang religius adalah orang yang bertingkah laku baik, sesuai ajaran agama yang dianutnya dalam kehidupan sehari-hari demi memperoleh rida atau perkenan Tuhannya.

Komponen-komponen dasar nilai religius dalam agama Islam yaitu iman (akidah), takwa (syariat), dan budi pekerti luhur (akhlakul karimah). Yanuar (2010: 1) mengungkapkan bahwa akidah berarti keyakinan yang tersimpul dengan kokoh di dalam hati, bersifat mengikat dan mengandung perjanjian. Dalam Islam, orang yang berakidah atau beriman meliputi orang yang beriman kepada Allah, kepada malaikat, kepada kitab-kitab Allah, kepada nabi dan rasul, kepada hari akhir, dan kepada takdir Allah.

Langgulung dalam Ali (2013: 365) mengungkapkan bahwa takwa adalah kata kunci untuk memahami sistem nilai (hal-hal yang penting dan berguna bagi kemanusiaan) dalam Islam. Takwa merupakan kesimpulan semua nilai yang terdapat dalam al-Quran, dan nilai-nilai dalam al-Quran tersebut dinyatakan sebagai akhlak (budi pekerti).

Nilai religius berupa takwa, mencakup segala nilai yang diperlukan manusia untuk keselamatan dan kebahagiaannya di dunia ini dan di akhirat kelak (Ali, 2013: 365). Adapun ruang lingkup nilai religius tersebut yaitu sebagai berikut. 
Religiusitas dalam Konteks ini meliputi beberapa unsur fundamental yaitu: Aqidah, syariah, akhlak dan ilmu Fiqih, empat hal dari unsur religi ini tidak dapat dipisahkan karena sangat berkaitan dengan yang lainnya.

Adapun eksistensialis yang dikemukakan oleh Simone de Beauvoir, Beauvoir mengatakan bahwa perempuan dalam eksistensinya di dunia ini hanya menjadi Liyan bagi laki-laki. Perempuan adalah objek dan laki-laki adalah subjeknya. Jadi eksistensialisme menurut Beauvoir yakni ketika perempuan tidak lagi menjadi Objek tetapi telah mejadi Subjek bagi dirinya, sehingga eksistensi perempuan pada hakikatnya sama dengan eksistensi manusia secara umum.

Novel berasal dari bahasa latin, Novus. Dalam bahasa itali disebut novella. Suatu prosa naratif yang lebih panjang daripada cerita pendek yang biasanya memerankan tokoh atau peristiwa imajiner. Novel adalah salah satu karya sastra prosa yang panjang yang mengandung rangkaian cerita kehidupan seseorang yang menonjolkan sifat dan watak tokoh.

Novel adalah cerita yang menggambarkan sebagian dari kehidupan seseorang atau beberapa orang yang sangat penting. Menurut Ibrahim (1987: 188) novel pada dasarnya sebuah cerita atau laporan mengenai kejadian atau suatu pengalaman, oleh karena itu kendala karya sastra tersebut dihargai sejajar dengan kebudayaan lain.

Dalam Kamus Besar Bahasa Indonesia (2008: 969), novel adalah karangan prosa yang panjang mengandung rangkaian cerita kehidupan seseorang dengan orang sekelilingnya dengan menonjolkan watak dan sifat setiap pelaku. Istilah novel berasal dan bahasa latin 'novellas' yang kemudian diturunkan menjadi 'novies', yang berarti baru. Perkataan baru ini dikaitkan dengan kenyataan bahwa novel merupakan jenis cerita fiksi (fiction) yang muncul belakangan dibandingkan dengan cerita pendek (short story) dan roman (Waluyo, 2002: 36).

Waluyo (2002: 36-37) menyatakan bahwa istilah novel mewakili dua pengertian, yakni pengertian yang sama dengan roman dan pengertian yang biasa digunakan untuk klasifikasi cerita menengah. Dalam novel terdapat: (1) perubahan nasib dari tokoh cerita, (2) ada beberapa episode dalam kehidupan tokoh utamanya, (3) biasanya tokoh utamanya tidak sampai mati.

Novel dalam arti umum adalah cerita berbentuk prosa dengan ukuran yang luas. Ukuran yang luas di sini dapat berarti cerita dengan plot yang kompleks, multi karakter, tema yang kompleks, suasana cerita yang beragam dan setting cerita yang beragam pula (Sumardjo dan Saini, 1986: 29). Keberagaman inilah yang membedakan novel dengan cerpen.

Novel merupakan sebuah karya fiksi prosa yang tertulis dan naratif, biasanya dalam bentuk cerita. Di dalam novel memang mempunyai panjang yang tertentu dan merupakan suatu cerita prosa yang fiktif. Hal itu sejalan dengan pendapat Nurgiyantoro (2005: 9) yang memberikan pengertian bahwa novel adalah sebuah prosa fiksi yang panjangnya cukup, artinya tidak terlalu panjang, namun juga tidak terlalu pendek. Meskipun imajinasi didasarkan atas kenyataan, tetapi imajinasi tidak sama dengan kenyataan yang dilukiskan.

Sumardjo dan Saini (1986: 29) berpendapat bahwa novel dapat diklasifikasikan menjadi tiga golongan yakni novel percintaan, novel petualangan, dan novel fantasi. Berdasarkan unsur fiksi novel dapat dibagi menjadi tiga yaitu 
novel plot, novel watak, novel tematis. 1) Novel plot atau novel kejadian. Novel ini mementingkan struktur cerita atau perkembangan kejadian. Novel ini biasanya banyak melukiskan ketegangan karena hanya mengisahkan kejadian. 2) Novel watak atau novel karakter. Novel ini mementingkan pengisahan watak karakter para pelakunya misalnya penakut, pemalas, humor, pemarah, mudah putus asa, mudah kecil hati, dan sebagainya. 3) Novel temantis. Novel ini mementingkan tema atau pokok persoalan yang sangat banyak.

\section{METODE}

Metode dalam penelitian ini menggunakan metode kualitatif. Sugiyono (2012: 36) berpendapat tentang penggunaan metode kualitatif dalam penelitian, yaitu untuk mengembangkan teori. Metode kualitatif paling cocok digunakan untuk mengembangkan teori yang dibangun melalui data yang diperoleh melalui lapangan. Teori yang demikian dibangun melalui grounded research. Dengan metode kualitatif peneliti pada awalnya melakukan penjelajahan, selanjutnya melakukan pengumpulan data yang mendalam sehingga ditemukan hipotesis yang berupa hubungan antargejala. Hipotesis tersebut diverifikasi dengan pengumpulan data yang mendalam. Bila hipotesis terbukti, maka akn menjadi tesis atau teori. Metode ini mengacu pada deskripsi data berupa kalimat-kalimat yang terdapat pada novel Cinta di Ujung Sajadah Karya Asma Nadia.

Data pada kalimat yang diambil adalah deskripsi paparan pengarang novel Cinta di Ujung Sajadah Karya Asma Nadia. Novel ini diterbitkan tahun 2012 oleh penerbit Republika. Nilai Religius yang menjadi fokus penelitian meliputi nilai aqidah, nilai syariah, dan nilai akhlak. Eksistensi perempuan juga dibatasi pada eksistensi perempuan sebagai pribadi, eksistensi perempuan sebagai anggota keluarga, dan eksistensi perempuan sebagai anggota masyarakat. Teknik penelitian dilakukan dengan meneliti data berupa kalimat-kalimat yang terdapat dalam novel Cinta di Ujung Sajadah Karya Asma Nadia.

Objek penelitian yang penulis lakukan ialah menganalisis nilai religius dan eksistensi perempuan dalam Novel Cinta di Ujung Sajadah karya Asma Nadia. Teknik catat merupakan teknik lanjutan yang dilakukan ketika menggunakan metode simak (Mahsun, 2005: 91). Teknik catat dilakukan dengan mencatat dan mengklasifikasikan data. Data yang dicatat disertakan pula kode datanya untuk pengecekan ulang terhadap sumber data yang diperlukan dalam rangka analisis data. Untuk selanjutnya, sumber data yang diperoleh dari artikel internet dicatat dan disertakan sumbernya.

Tahapan selanjutnya setelah data dikumpulkan adalah menganalisis data kemudian menyajikan hasil analisis data. Dalam pelaksanaannya, hasil analisis data biasa disajikan secara deskriptif. Pendapat ini dijelaskan oleh Siswantoro (2011: 81) yang memaparkan bahwa ciri utama paparan deskriptif ialah analisis yang dikerjakan berdasarkan tiap-tiap unsur yang sejenis.

Instrumen penelitian ini adalah peneliti sendiri (human instrument) yang dibantu dengan tabel analisis, bertujuan untuk mengumpulkan dan mengolah datadata sehingga dapat mempermudah peneliti dalam menganalisis serta 
mendeskripsikan analisis aspek idealisme dan aspek kepribadian dalam novel Cinta di Ujung Sajadah Karya Asma Nadia.

\section{HASIL DAN PEMBAHASAN}

Mendeskripsikan data merupakan menggambarkan data yang ada guna memperoleh bentuk nyata dari hasil analisis, sehingga lebih mudah dimengerti peneliti atau orang lain yang tertarik dengan hasil penelitian yang dilakukan.

Dalam penelitian kualitatif analisis data merupakan tahap yang bermanfaat untuk menelaah data yang telah diperoleh. Analsis yang penulis lakukan untuk memperoleh data dari novel Cinta di Ujung Sajadah yang telah dipilih selama penelitian berlangsung yaitu dengan teknik pustaka yaitu mempergunakan sumbersumber tertulis untuk memperoleh data dan konteks kesastraan dengan dunia nyata secara mimetik yang mendukung untuk dianalisis.

Sumber-sumber tertulis yang digunakan dipilih sesuai dengan masalah dan tujuan penelitian ini. Konteks kesastraan dapat dilengkapi dengan penjelasan dari sastrawan, kritikus, pembaca sastra, latar peristiwa dan situasi.

Berdasarkan hasil analisis nilai religius dalam novel Cinta di Ujung Sajadah karya Asma Nadia ditemukan 20 kutipan, yaitu:

Nilai akidah (keimanan) yang tertuang dalam rukun iman yang meliputi iman kepada Allah, iman kepada kitab-kitab Allah, iman kepada Rasul, iman kepada hari akhir, dan iman kepada takdir/ Qada'dan Qhadar. Dalam novel Cinta di Ujung Sajadah karya Asma Nadia ditemukan nilai akidah (keimanan) adalah 10 kutipan dengan prosentase $15,15 \%$.

Nilai syariah (ibadah), meliputi perintah mengerjakan salat, berdzikir dan berdoa kepada Allah, yang terdapat dalam novel Cinta di Ujung Sajadah karya Asma Nadia ditemukan 3 kutipan dengan persentase 4,55\%.

Nilai akhlak (budi pekerti), meliputi akhlak terhadap diri sendiri berupa sikap sabar, bersyukur, dan optimis, akhlak terhadap orang tua, dan akhlak terhadap sesama yang berupa sikap saling menasihati, menutup aurat, jujur, dan memberi salam yang terdapat dalam novel Cinta di Ujung Sajadah karya Asma Nadia ditemukan 7 kutipan dengan persentase 10,61\%.

Dalam novel Cinta di Ujung Sajadah karya Asma Nadia, eksistensi perempuan didapati 46 kutipan dan dikelompokkan menjadi tiga bagian, yaitu: eksistensi perempuan sebagai pribadi, eksistensi perempuan sebagai anggota keluaraga, eksistensi perempuan sebagai anggota masyarakat.

Eksistensi perempuan sebagai pribadi dalam novel Cinta di Ujung Sajadah karya Asma Nadia ini menggambarkan kekerasan hati seorang anak bertemu dengan ibunya, kekerasan hati seorang yang tidak mau mendengarkan pendapat orang lain, kemandirian seorang anak hidup tanpa kasih seorang ibu, kemandirian seorang anak untuk tidak menyusahkan orang tua, kesetiaan seorang pembantu kepada majikannya. Kemudian menggambarkan sifat yang religius tertanam dalam watak tokoh Cinta dan Aisyah yang berserah kepada Allah Swt., dan tokoh yang menggambarkan sifat memiliki pendirian dalam dirinya ketika di hadapkan dengan cobaan hidup. Dalam novel Cinta di Ujung Sajadah karya Asma Nadia terdapat 28 
kutipan dengan persentase $42,42 \%$.

Eksistensi perempuan sebagai anggota keluarga menggambarkan kelembutan seorang ibu kepada anaknya, kasih sayang seorang anak kepada ibunya dengan berbakti kepada ibunya, kasih sayang seorang ibu menjaga dan membesarkan anaknya, kesabaran seorang perempuan terhadap cobaan dan masalah hidupnya. Dalam novel Cinta di Ujung Sajadah karya Asma Nadia terdapat 13 kutipan dengan persentase 19,70\%.

Eksistensi perempuan sebagai anggota masyarakat menggambarkan kepedulianan terhadap dengan orang lain yang senantiasa memberikan nasihat, kekhawatiran terhadap orang tua, teman, sahabat. Menggambarkan hubungan seseorang dalam lingkungan yang baru, dapat hidup bertetangga, dan cara beradaptasi dengan lingkungan, menggambarkan seorang anak yang menghormati orang yang lebih tua, serta orang yang belum pernah di kenal atau asing. Dalam novel Cinta di Ujung Sajadah karya Asma Nadia terdapat 5 kutipan dengan persentase $7,57 \%$.

\section{SIMPULAN}

Dari hasil penelitian, penulis dapat menyimpulkan bahwa nilai-nilai religius yang terdapat dalam novel dan Cinta di Ujung Sajadah karya Asma Nadia paling dominan adalah nilai akidah (keimanan) dan eksistensi perempuan dalam novel ini paling dominan yaitu Eksistensi perempuan sebagai pribadi

\section{DAFTAR PUSTAKA}

Ali, M. D. (2013). Pendidikan Agama Islam. Depok: PT Rajagrafindo Persada. Asmuni, S. (1983). Dasar-dasar strategu da'wah. Surabaya: Al-Ikhlas.

Mahsun. (2005). Metode Penelitian Bahasa: Tahapan Strategi, Metode, dan Tekniknya. Jakarta: Raja Grafindo Persada.

Mangunwijaya, Y. B. (1982). Sastra dan Religiositas. Jakarta: Sinar Harapan.

Nadia, A. (2012). Cinta di Ujung Sajadah. Jakarta: Republika

Nurgiyantoro, B. (2005). Teori Pengkajian Fiksi. Yogyakarta: Gadjah Mada University Press, 2005

Sahlan, A. (2012). Religiusitas Perguruan Tinggi. Malang: UIN-Maliki Press.

Siswantoro. (2011). Metode Penelitian Sastra: Analisis Struktur Puisi. Yogyakarta: Pustaka Pelajar.

Sugiyono. (2015). Metodologi Penelitian Pendidikan. Bandung: Alfabeta.

Sumarjo, Y., \& Saini, K. M. (1986). Apresiasi kesusastraan. Gramedia.

Tim Penyusun Kamus Pusat Bahasa. (2008). Kamus Besar Bahasa Indonesia. Edisi

Keempat. Jakarta: Gramedia Pustaka Utama.

Waluyo, H. J. (2002). Pengkajian Sastra Rekaan. Salatiga: Widya Sari Press.

Yanuar, I. (2010). Kuliah Aqidah Islam. Yogyakarta: Lembaga Pengkajian dan Pengamatan Islam. 